\title{
ANALISIS TINGKAT KESEHATAN BANK PERKREDITAN RAKYAT (BPR) DENGAN METODE CAMEL DI KOTA BATAM
}

\author{
${ }^{1}$ Puspita Rama Nopiana, ${ }^{2}$ Mufidatul Chasanah \\ ${ }^{1}$ Universitas Putera Batam \\ puspitarama29@yahoo.com
}

\begin{abstract}
Bank an a financial institution that its role in supporting economic development in an area, which raised funds activities and disbursing funds in the form of loans or credit is a form of that money circulates to stabilize the economy. The purpose of this study was to conduct analysis of the banking healthy level on Bank Perkreditan Rakyat (BPR) in Batam City, for 2012-2016 periods. This research uses descriptive quantitative research design. The report data were extracted from bank's financial from financial report which had been published by Otoritas Jasa Keuangan (OJK). The assessment analysis of banking healthy level has been carried out by using CAMEL method (Capital, Asset, Management, Earning, and Liquidity) which is based on the decree of BI director No.30/12/KEP/DIR on April 30th, 1997. The results showed that the healthy level of Bank Perkreditan Rakyat (BPR) in Batam City for 2012-2016 periods showed categorized healthy, where the value - average CAR ratio of $13.68 \%$, KAP ratio of $1.76 \%$, NPM ratio of $16.51 \%$, ROA ratio of $3.86 \%$, BOPO ratio $78.01 \%$, and LDR ratio of $87.05 \%$. Expected for the future later $B P R$ could continue to keep even better, so the level of health can be guaranteed according to applicable regulations.
\end{abstract}

Keywords: Health of BPR, camel (CAR, KAP,NPM, ROA, BOPO, LDR)

\begin{abstract}
ABSTRAK
Bank merupakan lembaga keuangan yang berperan dalam menunjang perkembangan ekonomi dalam suatu daerah, yang mana kegiatan menghimpun dana dan menyalurkan dana dalam bentuk pinjaman atau pemberian kredit merupakan suatu bentuk perputaran uang untuk menstabilkan perekonomian.

Tujuan penelitian ini adalah untuk melakukan analisis terhadap tingkat kesehatan perbankan pada Bank Perkreditan Rakyat (BPR) di Kota Batam, untuk Tahun tahun 2012 - 2016. Penelitian ini menggunakan rancangan penelitian deskriptif kuantitatif. Data penelitian diambil dari laporan keuangan bank yang telah diterbitkan oleh Otoritas Jasa Keuangan (OJK). Analisis penilaian tingkat kesehatan perbankan menggunakan metode CAMEL (Capital, Asset, Management, Earning, Liquidity) yang berpedoman pada Surat Keputusan Direksi BI No.30/12/KEP/DIR tanggal 30 April 1997. Hasil penelitian menunjukkan bahwa tingkat kesehatan BPR di Kota Batam tahun 2012-2016 menunjukkan predikat yang Sehat, dimana nilai rata-rata rasio CAR sebesar 13,68\%, rasio KAP sebesar 1,76\%, rasio NPM 16,51\%, rasio ROA 3,86\%, rasio BOPO $78,01 \%$, dan rasio LDR 87,05\%. Diharapkan untuk kedepannya nanti BPR di Kota Batam bisa terus menjaga bahkan lebih baik lagi, sehingga tingkat kesehatannya dapat terjamin sesuai ketentuan yang berlaku.
\end{abstract}

Kata Kunci: Kesehatan BPR, CAMEL (CAR, KAP, NPM, ROA, BOPO, LDR)

\section{PENDAHULUAN}

Perkembangan perekonomian didukung oleh lembaga keuangan bank yang ada di Indonesia, dimana lembaga keuangan bank merupakan lembaga yang memberikan jasa keuangan yang paling lengkap. Usaha keuangan yang dilakukan depat berupa penyaluran dana atau memberikan pinjaman berupa kredit dan menghimpun dana dari masyarakat luasa dalam bentuk simpanan.
Usaha bank lainnya memberikan jasa-jasa keuangan yang mendukung dan memperlancar kegiatan memberikan pinjaman dengan kegiatan menghimpun dana. (Kasmir, 2014:27).

Bank Indonesia memiliki tugas untuk mengatur dan mengawasi setiap kegiatan perbankan, baik Bank Umum maupun Bank Perkreditan Rakyat (BPR). Bank Umum adalah bank yang melaksanakan kegiatan usaha secara 
konvensional dan/atau berdasarkan prinsip syariah yang dalam kegiatannya memberikan jasa dalam lalu lintas pembayaran, sedangkan Bank Perkreditan Rakyat (BPR) adalah bank yang melakukan kegiatan secara konvensional atau berdasarkan prinsip syariah yang dalam kegiatannya tidak memberikan jasa dalam lalu lintas pembayaran. Artinya, kefgiatan Bank Perkreditan Rakyat (BPR) lebih sempit dibandingkan dengan Bank Umum. (UndangUndang No. 10 Tahun 1998).

Penilaian kesehatan sebuah bank dapat dilakukan dengan pendekatan kualitatif melalui penilaian CAMEL yang terdiri dari beberapa komponen yang berpengaruh pada kondisi dan perkembangan sebuah bank, seperti permodalan (Capital), faktor Kualitas Aktiva (Assets), faktor Manajemen (Management), faktor Rentabilitas (Earning), dan faktor Likuiditas (Liquidity). Predikat penilaian terhadap kesehatan sebuah bank dinilai dengan empat kriteria tingkat kesehatan, yaitu Sehat, Cukup Sehat, Kurang Sehat, dan Tidak Sehat.

Penilaian dari faktor Permodalan (Capital) dapat diukur dengan rasio Capital Adequacy Ratio(CAR) atau sering disebut dengan

\section{Tabel 1. Perkembangan Kredit menurut Kolektibilitas Bank Perkreditan} Rakyat (BPR) di Kota Batam Tahun 2012-2016

\begin{tabular}{cccrrr}
\hline Tahun & $\begin{array}{c}\text { Kolektibiltas } \\
\text { Lancar }\end{array}$ & $\begin{array}{c}\text { Kolektibilitas } \\
\text { Kurang } \\
\text { Lancar }\end{array}$ & $\begin{array}{c}\text { Kolektibilitas } \\
\text { Diragukan }\end{array}$ & $\begin{array}{l}\text { Kolektibilitas } \\
\text { Macet }\end{array}$ & Jumlah Kredit \\
\hline 2012 & 1.842 .290 .976 & 25.400 .758 & 9.851 .262 & 13.066 .279 & 1.890 .609 .275 \\
2013 & 2.000 .262 .363 & 20.769 .984 & 10.071 .256 & 20.725 .777 & 2.051 .829 .380 \\
2014 & 2.426 .848 .016 & 18.773 .777 & 20.410 .861 & 23.519 .967 & 2.489 .552 .621 \\
2015 & 2.750 .778 .066 & 30.188 .837 & 16.059 .455 & 32.768 .079 & 2.829 .794 .437 \\
2016 & 3.110 .968 .065 & 48.925 .238 & 25.828 .436 & 45.416 .430 & 3.231 .138 .169 \\
\hline
\end{tabular}

Sumber Data: www.bi.go.id

Diketahui dari tabel 1, tingkat kolektibilitas kurang lancar mengalami penurunan pada tahun 2013 dan 2014, namun pada tahun 2015 dan 2016 mengalami kenaikan yang cukup signifikan. Hal tersebut dapat mempengaruhi laba pada usaha perbankan, selain itu dapat mempengaruhi tingkat kesehatan Bank Perkreditan Rakyat (BPR). Tingkat kolektibilitas yang diragukan diketahui pada tahun 2013 dan 2014 mengalami kenaikan, pada tahun 2015 mengalami penurunan namun pada tahun 2016 kembali mengalami kenaikan, hal tersebut memperlihatkan bahwa tingkat pengembalian kredit akan mengalami keterlambatan, yang mana dapat mempengaruhi struktur permodalan bank. Pada tingkat kolektibilitas macet setiap tahunnya mengalami kenaikan. Hal tersebut dapat mempengaruhi tingkat kepercayaan dari nasabah maupun pihak investor dalam menanamkan dana.
Kewajiban Penyedia Modal Minimum (KPMM) untuk menilai kecukupan modal bank dalam melakukan pengembangan usaha. Pada faktor Kualitas Aktiva (Assets) diukur dengan rasio Kualitas Aktiva Produktif (KAP) untuk menilai kelancaran dari pengembalian kredit yang diberikan kepada nasabah. Faktor Manajemen (Management) dinilai dari segi kemampuan bank dalam memperoleh net income dengan menggunakan rasio Net Profit Margin (NPM). Faktor Rentabilitas (Earning) di ukur dengan menggunakan rasio Return on Assets (ROA) dan juga Biaya Operasional terhadap Pendapatan Operasional (BOPO) untuk menilai kemampuan bank dalam mencapai laba dengan biaya yang dikeluarkan. Pada faktor Likuiditas (Liquidity) diukur dengan rasio Loan to Deposit Ratio (LDR) untuk menilai kemampuan bank dalam mengembalikan kewajibannya.

Perkembangan Bank Perkreditan Rakyat (BPR) di Kota Batam dilihat dati tingkat perkembangan kredit menurut kolektibilitas pada 27 Bank Perkreditan Rakyat (BPR) di Kota Batam selama Tahun 2012-2016, sebagai berikut: 


\section{Kesehatan Bank}

Penilai suatu kesehatan bank dapat dilihat dari berbagai aspek. Penilaian ini bertujuan untuk menentukan apakah bank tersebut dalam kondisi sehat., cukup sehat, kurang sehat dan tidak sehat. Sehingga Bank Indonesia sebagai pengawas dan pembina bank-bank dapat memberikan arahan atau petunjuk bagaimana bank tersebut harus dijalankan atau bahkan dihentikan kegiatan operasinya. Penilaian keseharan akan berpengaruh terhadap kemampuan bank dan loyalitas nasabah terhadap bank yang bersangkutan. Salah satu alat untuk mengukur kesehatan bank adalah dengan analisis CAMEL.

Analisis CAMEL

Camel adalah aspek yang paling banyak berpengaruh terhadap kondisi keuangan bank dan tingkat kesehatan bank. Camel merupakan tolak ukur yang menjadi objek pemeriksaan bank yang dilakukan oleh pengawas bank. Pendekatan CAMEL diatur dalam Surat Putusan Direksi Bank Indonesia No. 30/12/KEP/DIR tanggal 30 April 1997 tentang Tata Cara Penilaian Tingkat kesehatan Bank Umum dan Bank Perkreditan Rakyat (BPR). Aspek-aspek penilaian dalam analisis CAMEL terdiri atas 5 (lima) aspek, yaitu:

\section{Permodalan (Capital)}

Permodalan merupakan faktor utama dalam menjalankan kegiatan usaha, dimana modal dapat digunakan untuk mengembangkan usaha dan sebagai bentuk cadangan untuk mengantisipasi kemungkinan risiko-risiko yang mungkin saja dialami oleh bank. Faktor permodalan menurut (Darmawi, 2011:91) adalah kecukupan modal dan rasio untuk menguji kecukupan modal bank tersebut yaitu dengan menggunakan rasio Capital Adequacy Ratio (CAR). Rasio Capital Adequacy Ratio (CAR) adalah cara pembanding antara rasio modal bank terhadao Aktiva Tertimbang Menurut Risiko (ATMR). (Kasmir, 2015:300).

Dalam Surat Edaran No. 8/28/DPBPR tanggal 12 Desember 2006 tentang Kewajiban Penyedia Modal Minimum (KPMM) Bank Perkreditan Rakyat (BPR) diwajibkan untuk menyediakan modal minimum sebesar $8 \%$ dari Aktiva Tertimbang Menurut Risiko (ATMR).

\section{Kualitas Aktiva (Assets)}

Dalam Peraturan Bank Indonesia No. 8/19/PBI/2006 Aktiva Produktif adalah penyediaan dana BPR dalam rupiah untuk memperoleh penghasilan, dalam bentuk kredit, Sertifikat Bank Indonesia, dan Penempatan Dana Antar Bank. Rasio kualitas aktiva produktif (KAP) dapat dihitung dengan membandingkan antara Aktiva Produktif yang
Diklasifikasikan (APYD) terhadap total aktiva produktif. Perhitungan kualitas aktiva produktif menggambarkan bagaimana kondisi bank dalam mengelola kelancaran dalam tingkat pengembalian kredit dari debitur.

\section{Manajemen (Management)}

Penilaian terhadap faktor Manajemen mencakup 2 (dua) komponen yaitu manajemen umum dan manajemen risiko. Dalam manajemen umum dibagi lagi menjadi beberapa komponen, yaitu strategi sasaran, struktur, sistem, dan kepemimpinan. Untuk manajemen risiko juga terbagi lagi menjadi beberapa komponen risiko, yaitu likuiditasm kredit operasional, dan hukum. (Sudirman, 2013:120). Penilaian dari segi manajemen dinilai menggunakan rasio Net Profit Margin (NPM) yang dapat mengukur kemampuan bank dalam menghasilkan Net Income dari kegiatan operasi pokoknya.

\section{Rentabilitas (Earning)}

Dalam menentukan rentabilitas bank, tidak dapat dipisahkan antara dana yang dipakai untuk operasional bank dan untuk produktivitas bank serta ditentukan juga oleh biaya bank. (Sudirman, 2013:151) Penilaian faktor rentabilitas dengan menggunakan dua cara yaitu dengan rasio Return on Assets (ROA) dan perbandingan antara Biaya Operasional terhadap Pendapatan Operasional (BOPO).

\section{Likuiditas (Liquidity)}

Likuiditas adalah kemampuan bank untuk memenuhi kewajiban jangka pendek. Suatu bank dianggap likuid apabila bank tersebut mempunyai kesanggupan untuk membayar penarikan giro, tabungan, deposito berjangka, pinjaman bank yang segera jatuh tempo, pemenuhan permintaan kredit tanpa adanya suatu penundaan (kredit yang direalisasi). (Pandia, 2012:113). Penilaian likuiditas diukur dengan rasio Loan to Deposit Ratio (LDR) untuk mengetahui bagaimana kemampuan bank dalam membayar semua dana masyarakat dan modal sendiri dengan mengendalikan kredit yang telah didistribusikan ke masyarakat.

\section{METODE}

Metode yang digunakan dalam penelitian ini adalah metode penelitian kuantitatif deskriptif dengan menggunakan data sekunder yang berupa Laporan Keuangan Publikasi Triwulan ke-4 (empat) (Desember) Pada Bank Perkreditan Rakyat (BPR) di Kota Batam tahun 2012-2016 yang sudah di publukasi di website resmi Otoritas Jasa Keuangan (OJK). Adapun BPR yang dipilih dalam penelitian ini, yaitu: 1) PT BPR Dana Nusantara, 2) PT BPR Sejahtera Batam, 3) PT BPR Barelang Mandiri dan 4) PT 
BPR Dana Nagoya. Kemudian laporan keuangan publukasi Bank Perkreditan Rakyat (BPR) tersebut dilakukan analisis menggunakan pendekatan CAMEL sesuai ketentuan Surat Putusan Direksi Bank Indonesia No. 30/12/KEP/DIR tanggal 30 April 1997.

\section{HASIL DAN PEMBAHASAN}

Hasil analisis tingkat kesehatan Bank Perkreditan Rakyat (BPR) di Kota Batam dengan menggunakan metode CAMEL (Capital, Assets, Management, Earning, dan Liquidity) pada Tahun 2012-2015:

\section{Permodalan (Capital)}

Hasil analisis penilaian permodalan dengan menggunakan rasio Capital Adequacy Ratio (CAR) pada Bank Perkreditan Rakyat (BPR) di Kota Batam tahun 2012-2016 yaitu sebagai berikut:

Tabel 2. Nilai Capital Adequacy Ratio (CAR) Tahun 2012-2015

\begin{tabular}{|c|c|c|c|c|}
\hline Nama BPR & Total Modal & Total ATMR & CAR (\%) & Ket. \\
\hline \multicolumn{5}{|l|}{ Tahun 2012} \\
\hline 1. PT BPR Dana Nusantara & 63.527 .885 & 408.526 .774 & 15,63 & Sehat \\
\hline 2. PT BPR Sejahtera Batam & 28.589 .553 & 195.751 .100 & 14,61 & Sehat \\
\hline 3. PT BPR Barelang Mandiri & 23.568.498 & 192.297.312 & 12,26 & Sehat \\
\hline 4. PT BPR Dana Nagoya & 15.324 .432 & 82.054 .432 & 18,68 & Sehat \\
\hline \multicolumn{3}{|c|}{ Rata-rata Tahun 2012} & \multicolumn{2}{|l|}{15,29} \\
\hline \multicolumn{5}{|l|}{ Tahun 2013} \\
\hline 1. PT BPR Dana Nusantara & 66.707 .054 & 366.324 .875 & 18,21 & Sehat \\
\hline 2. PT BPR Sejahtera Batam & 31.706 .100 & 217.698.799 & 14,56 & Sehat \\
\hline 3. PT BPR Barelang Mandiri & 24.840 .025 & 197.629.535 & 12,57 & Sehat \\
\hline 4. PT BPR Dana Nogoya & 14.503 .483 & 102.243 .711 & 14,19 & Sehat \\
\hline \multicolumn{3}{|c|}{ Rata-rata Tahun 2013} & \multicolumn{2}{|l|}{14,88} \\
\hline \multicolumn{5}{|l|}{ Tahun 2014} \\
\hline 1. PT BPR Dana Nusantara & 67.775 .904 & 451.666 .899 & 15,01 & Sehat \\
\hline 2. PT BPR Sejahtera Batam & 39.391 .832 & 286.095.343 & 13,77 & Sehat \\
\hline 3. PT BPR Barelang Mandiri & 19.251 .616 & 186.831 .596 & 10,30 & Sehat \\
\hline 4. PT BPR Dana Nogoya & 17.522 .654 & 152.407 .141 & 11,50 & Sehat \\
\hline \multicolumn{3}{|c|}{ Rata-rata Tahun 2014} & \multicolumn{2}{|l|}{12,64} \\
\hline \multicolumn{5}{|l|}{ Tahun 2015} \\
\hline 1. PT BPR Dana Nusantara & 77.455 .054 & 531.632 .796 & 14,57 & Sehat \\
\hline 2. PT BPR Sejahtera Batam & 49.846 .998 & 380.949 .862 & 13,08 & Sehat \\
\hline 3. PT BPR Barelang Mandiri & 19.136.384 & 188.641 .628 & 10,14 & Sehat \\
\hline 4. PT BPR Dana Nogoya & 14.696.049 & 169.829 .266 & 8,65 & Sehat \\
\hline \multicolumn{3}{|c|}{ Rata-rata Tahun 2015} & \multicolumn{2}{|l|}{11,61} \\
\hline \multicolumn{5}{|l|}{ Tahun 2016} \\
\hline 1. PT BPR Dana Nusantara & 98.455 .936 & 777.072.967 & 12,67 & Sehat \\
\hline 2. PT BPR Sejahtera Batam & 65.369 .243 & 451.822 .257 & 14,47 & Sehat \\
\hline 3. PT BPR Barelang Mandiri & 21.567 .010 & 180.718 .822 & 11,93 & Sehat \\
\hline \multirow{2}{*}{\multicolumn{3}{|c|}{$\begin{array}{r}25.609 .269 \\
\text { Rata-rata Tahun } 2016\end{array}$}} & 16,95 & Sehat \\
\hline & & & 14,00 & \\
\hline
\end{tabular}

\section{Sumber: Hasil Pengolahan Data}

Hasil analisis tingkat kesehatan BPR di Kota Batam yang dinilai dari aspek permodalan tahun 2012-2016 selama 3 (tiga) tahun berturut-turut mengalami penurunan yaitu pada tahun 2013 mengalami penurunan sebesar $0,41 \%$ dari $15,29 \%$ menjadi 14,56\%. Pada tahun 2014 mengalami penurunan sebesar $2,24 \%$ dari $14,88 \%$ menjadi $12,64 \%$. Pada tahun 2015 mengalami penurunan sebesar $1,03 \%$ dari $12,64 \%$ menjadi $11,61 \%$. Namun pada tahun 2016 mengalami kenaikan sebesar 2,39\% dari $11,61 \%$ menjadi $14,00 \%$. Hal tersebut menunjukkan tingkat kesehatan BPR dalam predikat sehat dengan rata-rata sebesar 13,68\%.

Hasil persentase perhitungan CAR tersebut menunjukkan kondisi bank yang sehat. Hasil penilaian tersebut dapat dilihat bahwa Bank Perkreditan Rakyat (BPR) di Kota Batam mampu mengelola modal yang terdapat pada bank dan pihak bank juga mampu mengendalikan jumlah ATMR yang cukup baik sehingga hasil dari perbandingan tersebut mempunyai kelebihan modal yang berfungsi sebagai alat untuk mengantisipasi risiko yang mungkin terjadi pada usaha perbankan.

Hal tersebut dudukung penelitian terdahulu oleh (Tunena et al., 2015) yang menyatakan bahwa tingginya rasio kecukupan modal menggambarkan bahwa solvabilitas perbankan dalam kondisi yang memadai dalam menyerap risiko usahanya. CAR yang semakin tinggi menunjukkan kinerja bank yang semakin baik pula. 


\section{Kualitas Aktiva (Assets)}

Hasil analisis penilaian Kualitas Aktiva dengan menggunakan rasio Kualitas Aktiva
Produktif (KAP) pada Bank Perkreditan Rakyat (BPR) di Kota Batam tahun 2012-2016 yaitu sebagai berikut:

Tabel 8. Nilai Kualitas Aktiva Produktif (KAP) Tahun 2012-2016

\begin{tabular}{lrrrr}
\hline No. & \multicolumn{1}{c}{ Notal APYD BPR } & Total Aktiva Produktif & KAP(\%) & Ket. \\
\hline Tahun 2012 & & & & \\
1. PT BPR Dana Nusantara & 8.995 .981 & 503.778 .228 & 1,79 & Sehat \\
2. PT BPR Sejahtera Batam & 1.036 .552 & 220.529 .044 & 0,47 & Sehat \\
3. PT BPR Barelang Mandiri & 4.218 .269 & 201.128 .704 & 2,10 & Sehat \\
4. PT BPR Dana Nagoya & 942.176 & 92.478 .962 & 1,02 & Sehat \\
& & Rata-rata Tahun 2012 & $\mathbf{1 , 3 4}$ & \\
Tahun 2013 & & & & \\
1. PT BPR Dana Nusantara & 3.825 .316 & 504.760 .251 & 0,76 & Sehat \\
2. PT BPR Sejahtera Batam & 1.000 .684 & 257.633 .200 & 0,39 & Sehat \\
3. PT BPR Barelang Mandiri & 5.139 .188 & 236.913 .129 & 2,17 & Sehat \\
4. PT BPR Dana Nagoya & 1.539 .364 & 112.837 .037 & 1,36 & Sehat \\
& & Rata-rata Tahun 2013 & $\mathbf{1 , 1 7}$ & \\
Tahun 2014 & & & & \\
1. PT BPR Dana Nusantara & 2.348 .441 & 570.268 .014 & 0,41 & Sehat \\
2. PT BPR Sejahtera Batam & 671.865 & 318.532 .714 & 0,21 & Sehat \\
3. PT BPR Barelang Mandiri & 7.191 .538 & 221.601 .349 & 3,25 & Sehat \\
4. PT BPR Dana Nagoya & 2.548 .753 & 173.158 .216 & 1,47 & Sehat \\
& & Rata-rata Tahun 2014 & $\mathbf{1 , 3 3}$ & \\
Tahun 2015 & & & & \\
1. PT BPR Dana Nusantara & 8.613 .055 & 597.836 .926 & 1,44 & Sehat \\
2. PT BPR Sejahtera Batam & 964.447 & 419.705 .367 & 0,23 & Sehat \\
3. PT BPR Barelang Mandiri & 11.058 .104 & 216.407 .994 & 5,11 & Sehat \\
4. PT BPR Dana Nagoya & 2.970 .007 & 192.828 .938 & 1,54 & Sehat \\
& & Rata-rata Tahun 2015 & $\mathbf{2 , 0 8}$ & \\
Tahun 2016 & & & & \\
1. PT BPR Dana Nusantara & 12.459 .320 & 917.271 .213 & 1,36 & Sehat \\
2. PT BPR Sejahtera Batam & 1.700 .940 & 513.815 .799 & 0,33 & Sehat \\
3. PT BPR Barelang Mandiri & 16.883 .697 & 209.146 .872 & 8,07 & Sehat \\
4. PT BPR Dana Nagoya & 3.291 .757 & 190.732 .381 & 1,73 & Sehat \\
& & Rata-rata Tahun 2016 & $\mathbf{2 , 8 7}$ & \\
\hline
\end{tabular}

\section{Sumber: Hasil Pengolahan Data}

Hasil analisis tingkat kesehatan BPR di Kota Batam yang dinilai dari aspek kualitas aktiva tahun 2012-2016 pada tahun 2013 mengalami kenaikan sebesar $0,17 \%$ dari $1,34 \%$ menjadi $1,17 \%$. Pada tahun 2014 mengalami penurunan sebesar $0,16 \%$ dari $1,17 \%$ menjadi $1,33 \%$. Pada tahun 2015 mengalami penurunan sebesar $0,75 \%$ dari $1,33 \%$ menjadi $2,08 \%$. Pada tahun 2016 mengalami penurunan sebesar $0,79 \%$ dari 2,08\% menjadi 2,87\%. Dimana nilai Kualitas Aktiva Produktif dinilai sehat apa bila berada pada persentase antara $0 \%-10,35 \%$, artinya semakin kecil nilai KAP maka bank dinilai semakin sehat. Hasil dari perhitungan KAP selam tahun 2012-2016 menunjukkan tingkat kesehatan BPR dalam predikat sehat dengan rata-rata sebesar $1,76 \%$.

Hasil analisis penelitian aspek kualitas aktiva produktif ini menunjukkan bahwa tingkat kesehatan
Bank Perkreditan Rakyat (BPR) di Kota Batam selama 2012-2016 memiliki

predikat Sehat dengan nilai rata-rata sebesar $1,76 \%$. Hal ini berhubungan dengan kegiatan penghimpunan dana dan penyaluran dana dalam bentuk kredit yang harus dikelola dengan cukup baik. Apabila tingkat kolektibilitas pengembalian pinjaman atau kredit tidak dikelola dengan baik maka akan mempengaruhi tingkat kesehatan. Selain itu juga dapat menimbulkan kerugian pada usaha bank dan mempengaruhi modal bank.

Uraian tersebut didukung penelitian terdahulu oleh (Setiyono \& Aini, 2014) menyatakan bahwa semakin besar rasio KAP maka semakin tidak sehat bagi BPR, sehingga manajemen harus mengkaji ulang dalam pemberian kredit terhadap nasabah-nasabah. Besarnya rasio KAP dibawah 10,35\% menunjukkan BPR memiliki aktiva produktif bermasalah yang relative kecil. Karena semakin 
kecil rasio KAP, maka semakin besar tingkat kemungkinan diterimanya kembali dana yang ditanamkan.

Manajemen (Management)

Hasil analisis penilaian manajemen dengan menggunakan rasio Net Profit Margin (NPM) untuk menilai kemampuan BPR dalam menghasilkan Net Income dari kegiatan operational pokoknya. Hasil analisis rasio NPM tahun 2012-2016 yaitu sebagai berikut:

Tabel 9. Nilai Net Profit Margin (NPM) Tahun 2012-2016

\begin{tabular}{|c|c|c|c|c|}
\hline Nama BPR & Total Net Income & Total Operational Income & NPM (\%) & Ket. \\
\hline \multicolumn{5}{|l|}{ Tahun 2012} \\
\hline 1. PT BPR Dana Nusantara & 15.314 .416 & 88.105 .681 & 17,38 & Sehat \\
\hline 2. PT BPR Sejahtera Batam & 10.548 .724 & 41.878 .098 & 25,19 & Sehat \\
\hline 3. PT BPR Barelang Mandiri & 7.481 .930 & 37.348 .423 & 20,03 & Sehat \\
\hline \multirow[t]{2}{*}{ 4. PT BPR Dana Nagoya } & 6.100 .907 & 22.028 .894 & 27,70 & Sehat \\
\hline & & Rata-rata Tahun 2012 & $\mathbf{2 2 , 5 7}$ & \\
\hline \multicolumn{5}{|l|}{ Tahun 2013} \\
\hline 1. PT BPR Dana Nusantara & 13.369 .693 & 78.212 .106 & 17,09 & Sehat \\
\hline 2. PT BPR Sejahtera Batam & 8.692 .202 & 46.124 .603 & 18,85 & Sehat \\
\hline 3. PT BPR Barelang Mandiri & 8.971 .112 & 40.292 .729 & 22,26 & Sehat \\
\hline \multirow[t]{2}{*}{ 4. PT BPR Dana Nagoya } & 3.200 .721 & 22.382 .140 & 14,30 & Sehat \\
\hline & & Rata-rata Tahun 2013 & 18,12 & \\
\hline \multicolumn{5}{|l|}{ Tahun 2014} \\
\hline 1. PT BPR Dana Nusantara & 11.002 .076 & 86.755 .742 & 12,68 & Sehat \\
\hline 2. PT BPR Sejahtera Batam & 11.330 .773 & 55.685 .867 & 20,35 & Sehat \\
\hline 3. PT BPR Barelang Mandiri & 2.946 .565 & 38.657 .339 & 7,62 & Tidak sehat \\
\hline \multirow[t]{2}{*}{ 4. PT BPR Dana Nagoya } & 3.789 .280 & 28.887 .555 & 13,12 & Sehat \\
\hline & & Rata-rata Tahun 2014 & 13,44 & \\
\hline \multicolumn{5}{|l|}{ Tahun 2015} \\
\hline 1. PT BPR Dana Nusantara & 15.679 .576 & 108.713.566 & 14,42 & Sehat \\
\hline 2. PT BPR Sejahtera Batam & 15.188 .931 & 73.531 .233 & 20,66 & Sehat \\
\hline 3. PT BPR Barelang Mandiri & 1.031 .799 & 37.166 .625 & 2,78 & Tidak sehat \\
\hline \multirow[t]{2}{*}{ 4. PT BPR Dana Nagoya } & 6.036 .298 & 37.320 .530 & 16,17 & Sehat \\
\hline & & Rata-rata Tahun 2015 & 13,51 & \\
\hline \multicolumn{5}{|l|}{ Tahun 2016} \\
\hline 1. PT BPR Dana Nusantara & 25.070 .690 & 141.005 .655 & 17,78 & Sehat \\
\hline 2. PT BPR Sejahtera Batam & 19.022 .340 & 90.315 .364 & 21,06 & Sehat \\
\hline 3. PT BPR Barelang Mandiri & 2.529 .660 & 37.958 .129 & 6,66 & Tidak sehat \\
\hline \multirow[t]{2}{*}{ 4. PT BPR Dana Nagoya } & 5.130 .104 & 36.037 .953 & 14,24 & Sehat \\
\hline & & Rata-rata Tahun 2016 & 14,93 & \\
\hline
\end{tabular}

Sumber: Hasil Pengolahan Data

Hasil analisis tingkat kesehatan BPR di Kota Batam yang dinilai dari aspek manajemen tahun 2012-2016 selama 2 (dua) tahun berturut-turut mengalami penurunan yaitu pada tahun 2013 mengalami penurunan sebesar $4,45 \%$ dari $22,57 \%$ menjadi $18,12 \%$. Pada tahun 2014 mengalami penurunan sebesar $4,68 \%$ dari 18,12\% menjadi 13,44\%. Pada tahun 2015 mengalami kenaikan sebesar $0,07 \%$ dari $13,44 \%$ menjadi 13,51\%. Pada tahun 2016 mengalami kenaikan sebesar $1,42 \%$ dari $13,51 \%$ menjadi $14,93 \%$. Dimana hasil persentase rasio menunjukkan tingkat kesehatan BPR dalam predikat sehat dengan rata-rata sebesar $16,51 \%$.

Hasil tersebut juga menunjukkan bahwa bank mampu dalam menghasilakan laba secara optimal.

Menurut Rizky dalam penelitian (Laluas, Mangantar, \& Mekel, 2014) menjelaskan bahwa pendekatan manajemen mengacu pada pengukuran terhadap manajemen umum dan manajemen risiko dengan menggunakan kuisoner, tapi pengukuran menggunakan kuisoner sangat sulit untuk dilakukan karena berhubungan erat dengan kerahasiaan suatu bank atau aspek-aspek intern bank yang tidak sembarangan dipublikasi. Berdasarkan hal tersebut digunakan rasio Net Profit Margin (NPM). Hal ini dikarenakan rasio NPM erat kaitannya dengan aspek-aspek manajemen yang dinilai baik dalam manajemen umum maupun manajemen risiko dimana Net Income dalam aspek manajemen umum mencerminkan hasil dari strategi dari keputusan yang dijalankan dalam tekniknya dijabarkan dalam bentuk sistem pencatatan, pengamanan, dan pengawasan dari kegiatan operasional bank dalam memperoleh Operational Income yang optimal. Sedangkan Net Income dalam manajemen risiko mencerminkan pengukuran terhadap upaya mengeliminir risiko likuidita, risiko kredit, risiko operasional, risiko hukum, dan risiko pemilik dari kegiatan operasional bank. Untuk memperoleh Operational Income yang optimal. 


\section{Rentabilitas (Earning)}

Hasil analisis penilaian rentabilitas dengan menggunakan rasio Return on Assets (ROA) dan rasio Biaya Operasional terhadap Pendapatan Operasional (BOPO) pada Bank Perkreditan Rakyat (BPR) di Kota Batam selama Tahun 2012-2016. Hasil analisis ROA dan BOPO yaitu sebagai berikut:

\section{Return on Assets (ROA)}

Hasil analisis dari aspek rentabilitas dengan menggunakan rasio Return on Assets (ROA) pada Bank Perkreditan Rakyat (BPR) di Kota Batam Tahun 2012-2016 dirangkum dalam tabel berikut ini:

Tabel 10. Nilai Return on Assets (ROA) 2012-2016

\begin{tabular}{|c|c|c|c|c|}
\hline Nama BPR & Total Laba sebelum Pajak & Total Aktiva & ROA (\%) & Ket. \\
\hline \multicolumn{5}{|l|}{ Tahun 2012} \\
\hline 1. PT BPR Dana Nusantara & 20.733.732 & 542.931 .128 & 3,82 & Sehat \\
\hline 2. PT BPR Sejahtera Batam & 14.324 .749 & 235.428 .070 & 6,08 & Sehat \\
\hline 3. PT BPR Barelang Mandiri & 9.975 .907 & 221.994 .625 & 4,49 & Sehat \\
\hline \multirow{2}{*}{ 4. PT BPR Dana Nagoya } & 7.854.383 & 103.411 .662 & 7,60 & Sehat \\
\hline & \multicolumn{2}{|c|}{ Rata-rata Tahun 2012} & $\mathbf{5 , 5 0}$ & \\
\hline \multicolumn{5}{|l|}{ Tahun 2013} \\
\hline 1. PT BPR Dana Nusantara & 18.029 .576 & 517.099 .684 & 3,49 & Sehat \\
\hline 2. PT BPR Sejahtera Batam & 12.098 .549 & 262.545 .166 & 4,61 & Tidak sehat \\
\hline 3. PT BPR Barelang Mandiri & 11.808 .966 & 249.245 .460 & 4,74 & Sehat \\
\hline \multirow[t]{2}{*}{ 4. PT BPR Dana Nagoya } & 4.211 .550 & 116.083 .705 & 3,63 & Sehat \\
\hline & \multicolumn{2}{|c|}{ Rata-rata Tahun 2013} & 4,12 & \\
\hline \multicolumn{5}{|l|}{ Tahun 2014} \\
\hline 1. PT BPR Dana Nusantara & 15.403.119 & 585.918 .298 & 2,63 & Sehat \\
\hline 2. PT BPR Sejahtera Batam & 15.196 .123 & 322.581 .155 & 4,71 & Sehat \\
\hline 3. PT BPR Barelang Mandiri & 4.561 .887 & 237.501.978 & 1,92 & Sehat \\
\hline \multirow[t]{2}{*}{ 4. PT BPR Dana Nagoya } & 5.280 .175 & 175.434 .494 & 3,01 & Sehat \\
\hline & \multicolumn{2}{|c|}{ Rata-rata Tahun 2014} & $\mathbf{3 , 0 7}$ & \\
\hline \multicolumn{5}{|l|}{ Tahun 2015} \\
\hline 1. PT BPR Dana Nusantara & 21.510 .480 & 612.190 .926 & 3,51 & Sehat \\
\hline 2. PT BPR Sejahtera Batam & 20.621 .904 & 427.508 .135 & 4,82 & Sehat \\
\hline 3. PT BPR Barelang Mandiri & 1.577 .619 & 226.778 .410 & 0,70 & Tidak sehat \\
\hline \multirow[t]{2}{*}{ 4. PT BPR Dana Nagoya } & 7.784 .951 & 201.237.840 & 3,87 & Sehat \\
\hline & \multicolumn{2}{|c|}{ Rata-rata Tahun 2015} & 3,22 & \\
\hline \multicolumn{5}{|l|}{ Tahun 2016} \\
\hline 1. PT BPR Dana Nusantara & 34.475 .572 & 945.210 .811 & 3,65 & Sehat \\
\hline 2. PT BPR Sejahtera Batam & 25.780 .447 & 526.852 .516 & 4,89 & Sehat \\
\hline 3. PT BPR Barelang Mandiri & 3.571 .601 & 218.997.331 & 1,63 & Sehat \\
\hline 4. PT BPR Dana Nagoya & 6.672 .305 & 202.115.471 & 3,30 & Sehat \\
\hline \multicolumn{3}{|r|}{ a Tahun 2016} & 3,37 & \\
\hline
\end{tabular}

Sumber: Hasil Pengolahan Data

Hasil analisis tingkat kesehatan BPR di Kota Batam yang dinilai dari aspek rentabilitas dengan rasio ROA tahun 2012-2016 selama 2 (dua) tahun berturut-turut mengalami penurunan yaitu pada tahun 2013 mengalami penurunan sebesar $1,38 \%$ dari $5,50 \%$ menjadi $4,12 \%$. Pada tahun 2014 mengalami penurunan sebesar $1,05 \%$ dari $4,12 \%$ menjadi $3,07 \%$. Pada tahun 2015 mengalami kenaikan sebesar $0,15 \%$ dari $3,07 \%$ menjadi 3,22\%. Pada tahun 2016 mengalami kenaikan sebesar $0,15 \%$ dari $3,22 \%$ menjadi 3,37\%. Dimana hasil persentase rasio ROA dikatakan sehat jika hasil persentase lebih dari $1,22 \%$. Hal tersebut menunjukkan tingkat kesehatan BPR dalam predikat sehat dengan rata-rata sebesar $3,86 \%$.

\section{Biaya Operasional Pendapatan Operasional (BOPO)}

Hasil analisis Biaya Operasional Pendapatan Operasional (BOPO) pada Bank Perkreditan Rakyat (BPR) di Kota Batam selama Tahun 2012-2016, yaitu sebagai berikut:

\section{Tabel 11. Nilai Biaya Operasional Pendapatan Operasional (BOPO)}

Tahun 2012-2016

\begin{tabular}{lrrrr}
\hline No. $\quad$ Nama BPR & $\begin{array}{c}\text { Total Biaya } \\
\text { Operasional }\end{array}$ & $\begin{array}{c}\text { Total Pendapatan } \\
\text { Operasional }\end{array}$ & $\begin{array}{c}\text { BOPO } \\
(\%)\end{array}$ & Ket. \\
\hline Tahun 2012 & & & & \\
1. PT BPR Dana Nusantara & 70.411 .809 & 88.105 .680 & 79,92 & Sehat \\
2. PT BPR Sejahtera Batam & 27.980 .099 & 41.878 .098 & 66,81 & Sehat \\
\hline
\end{tabular}


27.455 .230

14.005 .684

4. PT BPR Dana Nagoya

Tahun 2013

1. PT BPR Dana Nusantara

64.045 .025

2. PT BPR Sejahtera Batam

3. PT BPR Barelang Mandiri

4. PT BPR Dana Nagoya

Tahun 2014

1. PT BPR Dana Nusantara

2. PT BPR Sejahtera Batam

3. PT BPR Barelang Mandiri

4. PT BPR Dana Nagoya

Tahun 2015

1. PT BPR Dana Nusantara

2. PT BPR Sejahtera Batam

3. PT BPR Barelang

Mandiri

4. PT BPR Dana Nagoya

\section{Tahun 2016}

1. PT BPR Dana Nusantara

2. PT BPR Sejahtera Batam

3. PT BPR Barelang

Mandiri

4. PT BPR Dana Nagoya
33.893 .407

28.491.218

16.925 .940

76.155 .019

41.972 .067

33.676 .220

22.362 .724

89.276 .911

54.464 .677

35.566 .991

28.920 .983

108.655 .522

66.106 .879

34.441 .566

27.663.509

37.348 .423

73,51

Sehat

22.028 .894

63,58

Rata-rata Tahun 2012

$\mathbf{7 0 , 9 5}$

78.212 .106

81,89

46.124 .603

73,48

40.292 .729

70,71

22.382 .140

75,62

Rata-rata Tahun 2013

$\mathbf{7 5 , 4 2}$

86.755 .742

87,78

55.685 .867

75,37

Sehat

38.657 .339

87,11

Sehat

28.887 .555

77,41

81,92

Rata-rata Tahun 2014

108.713 .566
73.531 .233
37.166 .625
37.320 .530

82,12

74,07

95,70

77,49

Rata-rata Tahun 2015

82,34

141.005 .655
90.315 .364
37.958 .129
36.037 .953

77,06

73,20

Sehat

Sehat

\begin{tabular}{rrr}
37.958 .129 & 90,74 & Sehat \\
36.037 .953 & 76,76 & Sehat \\
Rata-rata Tahun 2016 & $\mathbf{7 9 , 4 4}$ & \\
\hline
\end{tabular}

\section{Sumber: Hasil Pengolahan Data}

Hasil analisis tingkat kesehatan BPR di Kota Batam yang dinilai dari aspek rentabilitas dengan rasio BOPO tahun 2012-2016 yaitu tahun 2013 mengalami penurunan sebesar $4,47 \%$ dari $70,95 \%$ menjadi $75,42 \%$. Pada tahun 2014 mengalami penurunan sebesar $6,05 \%$ dari $75,42 \%$ menjadi $81,92 \%$. Pada tahun 2015 mengalami penurunan sebesar $0,42 \%$ dari $81,92 \%$ menjadi 82,34\%. Pada tahun 2016 mengalami kenaikan sebesar 2,9\% dari $82,34 \%$ menjadi $79,44 \%$. Dimana hasil persentase rasio BOPO dikatakan sehat jika hasil persentase kurang dari $93,52 \%$. Hal tersebut menunjukkan tingkat kesehatan BPR dalam predikat sehat dengan rata-rata sebesar $78,01 \%$.

Hasil persentase ROA dan BOPO menunjukkan kemampuan bank dalam meningkatkan laba dan efesiensi usaha yang dicapainya. Salah satu indikator untuk mengukur tingkat kesehatan bank adalah kemampuan bank dalam memperoleh laba dan tingkat efektivitas manajemen dalam menjalankan operasional perusahaannya.

Hasil penilaian ROA dan BOPO dikatakan sehat didukung penelitian terdahulu oleh (Laluas et al., 2014) yang menyatakan bahwa kinerja dalam aspek rentabilitas (earning) menunjukkan tingkat efisiensi kinerja yang sangat baik. Selain itu didukung pula dengan teori (Kasmir, 2014:45) yang menyatakan bahwa aspek rentabilitas untuk mengukur kemampuan bank dalam meningkatkan labanya, setiap periode atau untuk mengukur tingkat efisiensi usaha dan profitabilitas yang dicapai bank yang bersangkutan.

\section{Likuiditas (Liquidity)}

Hasil analisis penilaian likuiditas dengan menggunakan rasio Loan to Deposit Ratio (LDR) pada Bank Perkreditan Rakyat (BPR) di Kota Batam. Hasil analisis rasio LDR tahun 2012-2016 yaitu sebagai berikut:

Tabel 12. Nilai Loan to Deposit Ratio (LDR) Tahun 2012-2016

\begin{tabular}{|c|c|c|c|c|c|}
\hline No. & Nama BPR & Total Kredit & Total DPK & $\operatorname{LDR}(\%)$ & Ket. \\
\hline \multicolumn{6}{|c|}{ Tahun 2012} \\
\hline 1. & PT BPR Dana Nusantara & 355.488 .978 & 442.880 .927 & 80,27 & Sehat \\
\hline & PT BPR Sejahtera Batam & 178.189 .711 & 200.066 .673 & 89,07 & Sehat \\
\hline & PT BPR Barelang Mandiri & 167.569 .868 & 181.836 .346 & 92,15 & Sehat \\
\hline & PT BPR Dana Nagoya & 71.275 .674 & 84.334 .848 & 84,52 & Sehat \\
\hline
\end{tabular}


Tahun 2013

1. PT BPR Dana Nusantara

2. PT BPR Sejahtera Batam

3. PT BPR Barelang Mandiri

4. PT BPR Dana Nagoya

Tahun 2014

1. PT BPR Dana Nusantara

2. PT BPR Sejahtera Batam

3. PT BPR Barelang Mandiri

4. PT BPR Dana Nagoya

\section{Tahun 2015}

1. PT BPR Dana Nusantara

2. PT BPR Sejahtera Batam

3. PT BPR Barelang Mandiri

4. PT BPR Dana Nagoya

\section{Tahun 2016}

1. PT BPR Dana Nusantara

2. PT BPR Sejahtera Batam

3. PT BPR Barelang Mandiri

4. PT BPR Dana Nagoya
Rata-rata Tahun 2012

$\begin{array}{rr}315.562 .914 & 430.605 .206 \\ 199.783 .385 & 225.531 .189 \\ 172.269 .491 & 213.388 .494 \\ 94.797 .862 & 96.931 .559 \\ \text { Rata-rata Tahun 2013 }\end{array}$

$\begin{array}{ll}403.460 .117 & 485.338 .595 \\ 270.673 .010 & 277.416 .101 \\ 158.182 .040 & 209.680 .464 \\ 142.610 .211 & 147.278 .974\end{array}$

Rata-rata Tahun 2014

$\begin{array}{ll}495.553 .903 & 505.417 .188 \\ 359.198 .850 & 370.254 .491 \\ 164.671 .359 & 199.661 .872 \\ 152.269 .004 & 176.270 .932\end{array}$

Rata-rata Tahun 2015

\section{$706.515 .385 \quad 774.036 .112$ \\ 417.033.524 453.086.415 \\ $157.094 .837 \quad 190.323 .125$ \\ $125.544 .438 \quad 174.810 .092$}

Rata-rata Tahun 2016
86,50

$\begin{array}{lc}73,28 & \text { Sehat } \\ 88,58 & \text { Sehat } \\ 80,73 & \text { Sehat } \\ 97,80 & \text { Cukup sehat } \\ \mathbf{8 5 , 1 0} & \end{array}$

83,13 Sehat

97,57 Cukup sehat

75,44 Sehat

96,83 Cukup sehat

$\mathbf{8 8 , 2 4}$

$\begin{array}{cc}98,05 & \text { Cukup sehat } \\ 97,01 & \text { Cukup sehat } \\ 82,48 & \text { Sehat } \\ 86,38 & \text { Sehat } \\ \mathbf{9 0 , 9 8} & \\ & \\ 91,28 & \text { Sehat } \\ 92,04 & \text { Sehat } \\ 82,54 & \text { Sehat } \\ \mathbf{7 1 , 8 2} & \text { Sehat } \\ \mathbf{8 4 , 4 2} & \end{array}$

\section{Sumber: Hasil Pengolahan Data}

Hasil analisis tingkat kesehatan BPR di Kota Batam yang dinilai dari aspek likuiditas tahun 2012-2016 yaitu pada tahun 2013 mengalami kenaikan sebesar $1,40 \%$ dari $86,50 \%$ menjadi $85,10 \%$. Pada tahun 2014 mengalami penurunan sebesar 3,14\% dari 85,10\% menjadi 88,24\%. Pada tahun 2015 mengalami penurunan sebesar $2,74 \%$ dari $88,24 \%$ menjadi $90,98 \%$. Pada tahun 2016 mengalami kenaikan sebesar $6,56 \%$ dari $90,98 \%$ menjadi $84,42 \%$. Dimana hasil persentase rasio LDR menunjukkan tingkat kesehatan BPR dalam predikat sehat dengan rata-rata sebesar $87,05 \%$.

Hasil tersebut menunjukkan bahwa BPR dinilai mampu dalam mengendalikan dana yang diterima dengan penyaluran kredit kepada nasabah.

Sejalan dengan penelitian terdahulu oleh (Setiyono \& Aini, 2014) yang menyatakan bahwa penting bagi BPR dalam memberikan jumlah kredit harus lebih rendah dibandingkan jumlah dana yang diterima, dimana LDR dinilai sehat apabila nilai persentase berada di bawah $94,75 \%$.

\section{SIMPULAN}

Secara keseluruhan hasil dari analisis tingkat kesehatan Bank Perkreditan Rakyat (BPR) di Kota Batam tahun 2012-2016 dalam kondisi sehat dengan rata-rata hasil persentase rasio CAR sebesar 13,68\%, rasio KAP sebesar 1,76\%, rasio NPM sebesar 16,51, rasio ROA dan BOPO sebesar $3,86 \%$ dan $78,01 \%$ dan rasio LDR sebesar $87,05 \%$.
Faktor penilaian dengan metode CAMEL dinilai sangat efektif untuk menilai tingkat kesehatan sebuah Bank Perkreditan Rakyat (BPR), sehingga pihak BPR dapat mengetahui pada faktor apa yang harus di perbaiki apabila terjadi penilaian yang tidak sehat dapat segera di atasi.

\section{DAFTAR PUSJAKA}

Bank Indonesia. (n.d.). Mengenal Bank Perkreditan Rakyat (BPR). Retrieved June 24, 2017, from http://www.bi.go.id/id/perbankan/edukasi/ Documents/ea49c9c9dd4546b98c3521cf5e e25d12MengenalBPR.pdf

Bank Indonesia. Pereturan Bank Indonesia: Kualitas Aktiva Produktif dan Pembentukan Penyisihan Penghapusan Aktiva Produktif BPR, Pub. L. No. 8/19/PBI/2006 (2006). Jakarta.

Bank Indonesia. Surat Edaran: Kewajiban Penyedia Modal Minimum BPR, Pub. L. No. 8/28/DPBPR, Bank Indonesia (2006). Jakarta, Jakarta.

Darmawi, H. (2011). Manajemen Perbankan (Ed. Ke 1). Jakarta: Bumi Aksara.

Jacob, J. K. D., Keuangan, A. L., Laporan, A., Dengan, K., Metode, M., Menilai, U., ... Manado, R. (2013). Analisis Laporan Keuangan Dengan Menggunakan Metode Camel Untuk Menilai Tingkat Kesehatan Perbankan. Jurnal EMBA, 1(3), 691-700.

Kasmir. (2014). Bank dan Lembaga Keuangan Lainnya (Ed. Revisi). Jakarta: PT Raja Grafindo Persada. 
Kasmir. (2015). Manajemen Perbankan (Ed. Revisi). Jakarta: PT Raja Grafindo Persada.

Laluas, A. A. ., Mangantar, M., \& Mekel, P. A. (2014). Analisis Kinerja Bank BUMN Menggunakan Metode Camel. Jurnal EMBA, 2(3), 176-184.

Latumaerissa, J. R. (2011). Bank dan Lembaga Keuangan Lain. Jakarta: Salemba Empat.

Pandia, F. (2012). Manajemen Dana dan Kesehatan Bank. Jakarta: Rineka Cipta.

Pemerintah Indonesia. Undang-Undang No. 10 Tahun 1998 Perbankan, Pub. L. No. 10 (1998). Jakarta.

Setiyono, W. P., \& Aini, M. N. (2014). Analisis Kinerja Keuangan Perbankan Dengan Menggunakan Metode Camel (Studi Kasus Pada PT. BPR Buduran Delta Purnama). Jurnal Bisnis, Manajemen \& Perbankan, 1(2), 175-196.

Sudirman, I. W. (2013). Manajemen Perbankan: Menuju Bankir Konvensional yang Profesional (Pertama). Jakarta: Kencana Prenada Media Group.

Sundari. (2015). Analisis Penilaian Tingkat Kesehatan Bank (Study Kasus Pada PD. BPR BKK Boyolali Kota). Bhirawa, 2(2), $1-11$.

Tunena, A., Lapian, S. L. V. . J., \& Sepang, J. L. (2015). Analisis tingkat kesehatan bank dengan metode camel (studi perbandingan pada bri tbk \& btn tbk periode 2010-2014). Jurnal EMBA, 3(3), 1349-1357.

Zahara. (2013). Analisis Tingkat Kesehatan Bank Perkreditan Rakyat (BPR) Dengan Metode Camel (Studi Kasus Pada Tiga BPR di Sumatera Barat). Jurnal Akuntansi \& Manajemen, 8(2), 61-75. 